This item was submitted to Loughborough's Research Repository by the author.

Items in Figshare are protected by copyright, with all rights reserved, unless otherwise indicated.

\title{
Educational mobility and the gendered geography of cultural capital: the case of international student flows between Central Asia and the UK
}

PLEASE CITE THE PUBLISHED VERSION

http://dx.doi.org/10.1068/a44655

PUBLISHER

(C) Pion and its Licensors

VERSION

AM (Accepted Manuscript)

LICENCE

CC BY-NC-ND 4.0

\section{REPOSITORY RECORD}

Holloway, Sarah L., Sarah L. O'Hara, and Helena Pimlott-Wilson. 2019. "Educational Mobility and the Gendered Geography of Cultural Capital: The Case of International Student Flows Between Central Asia and the UK". figshare. https://hdl.handle.net/2134/13798. 
This item was submitted to Loughborough's Institutional Repository (https://dspace.lboro.ac.uk/) by the author and is made available under the following Creative Commons Licence conditions.

\section{creative
commons}

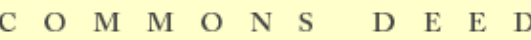

Attribution-NonCommercial-NoDerivs 2.5

You are free:

- to copy, distribute, display, and perform the work

Under the following conditions:

Attribution. You must attribute the work in the manner specified b the author or licensor.

Noncommercial. You may not use this work for commercial purposes.

No Derivative Works. You may not alter, transform, or build upon this work.

- For any reuse or distribution, you must make clear to others the license terms of this work.

- Any of these conditions can be waived if you get permission from the copyright holder.

Your fair use and other rights are in no way affected by the above.

This is a human-readable summary of the Leqal Code (the full license).

\section{Disclaimer 만}

For the full text of this licence, please go to: http://creativecommons.org/licenses/by-nc-nd/2.5/ 


\title{
Educational mobility and the gendered geography of cultural capital: the case of international student flows between Central Asia and the UK ${ }^{1}$
}

Sarah L. Holloway, Sarah L. O’Hara and Helena Pimlott-Wilson

To cite this paper: Holloway, S.L., O’Hara, S.L. \& Pimlott-Wilson, H. (2012)

Educational mobility and the gendered geography of cultural capital: the case of international student flows between Central Asia and the UK Environment and Planning A 44.9: 2278 - 2294

\begin{abstract}
International student mobility from East to West has grown rapidly as the middleclasses have sought to reproduce their advantage in the context of changing socioeconomic circumstances. Existing research shows that middle-class students and their parents are increasingly using overseas educational qualifications - an institutionalised form of cultural capital - to ensure they stand out in the competition for lucrative employment. This paper makes two unique contributions to these debates. Firstly, it broadens the spatial frame away from East Asia to the emerging educational markets in post-Soviet Central Asia, and specifically Kazakhstan. This shift allows examination of similarities in students' accrual of cultural capital between regions, but also highlights spatial specificity in these flows. Secondly, it moves beyond narrowly class-based approaches to spotlight the importance of gender, sexuality and religion in geographies of cultural capital. Middle-class social reproduction helps drive international student mobility, but class is experienced differently by young men and women in the context of locally-specific forms of heterosexuality, which in this case-study reflect the cultural importance of Islam. Class matters, but to fully understand its importance in student mobility we must trace its intersections with other axes of social difference.
\end{abstract}

\footnotetext{
${ }^{1}$ All authors made an equally valuable contribution to this research.
} 
Keywords: Higher education; international student mobility; cultural capital; class; gender; heterosexuality; religion.

\section{Introduction}

Geographers' interest in education has grown rapidly since the turn of the twenty-first century, and research into the internationalisation of higher education has played an important role in the development of this field (Holloway et al., 2010). This paper focuses on one facet this internationalisation, namely the growth in student mobility between East and West over the past three decades. Existing research shows that changing socio-economic circumstances which place pressure on middle-class social reproduction in East Asia have been a key stimulus to growth (Huang and Yeoh, 2005; Lee H, 2010; Waters, 2006a; Xiang and Shen, 2009). In the face of challenges to families’ ability to pass class status on from one generation to another, middle-class students and their parents are increasingly using overseas educational qualifications - an institutionalised form of cultural capital - to ensure they stand out from the crowd in the competition for lucrative employment opportunities and associated lifestyles. The cultural capital they gain by studying abroad is spatially sensitive, and often most easily realised through return to a home country (Waters, 2006b).

In this paper we make two unique contributions to our understanding cultural capital and its role in international student mobility. Firstly, we broaden the spatial frame of research away from East Asia to the emerging educational markets in postSoviet Central Asia, and in particular Kazakhstan. This shift allows us to examine similarities in students' accrual of cultural capital between regions, but also highlights a degree of spatial specificity in the nature, meaning and implications of these flows. Secondly, we move beyond narrowly class-based approaches to spotlight the central importance of gender and family life in geographies of cultural capital. Middle-class social reproduction is a core driver of international student mobility, but as we demonstrate class is experienced in significantly different ways by young men and women in the context of locally-specific forms of heterosexuality, forms which in our case-study reflect the cultural importance of Islam. Class matters, but as this study shows to fully understand its importance in student mobility we must trace its intersections with other axes of social difference. 
We begin below by establishing the rationale for our study through a review of the literature. The paper then turns to our case study research and we examine what can be learnt from our young male and female interviewees who had moved from Kazakhstan to study in the UK.

\section{International student mobility, cultural capital, and gender}

International student mobility has grown rapidly over the past three decades, with increasing numbers of students travelling to study at school, undergraduate and postgraduate level outside their country of origin. These movements have been dominated by flows from Asia (and to a lesser extent Africa and the Middle-East) to the Global North (including Australia, Canada, France, Germany, the UK and the USA) reflecting the uneven development of the global education industry and, to a lesser extent, the dominance of the English language (Findlay, 2010). However, flows of students between countries within the global North are also important (Brooks and Waters, 2009; Findlay et al. 2012; King et al., 2011), as are emerging destinations, such as Singapore, which has sought to establish itself as a world-class education hub (Olds, 2007). The education industries in the receiving countries are an important influence on these flows, as at both school and University level they have responded to neoliberal reform by seeking to attract fee-paying international students in order to sustain and develop their sector through times of fiscal difficulty (Findlay 2010; Madge et al. 2009; Waters 2006a). The market in international higher education students was, for example, worth $£ 5$ billion in the United Kingdom alone in 2006 (Findlay, 2010) where 11\% of students are from countries outside the European Union (HESA, 2011) .

This expansionary drive from within the Global North has come together with demand for international educational experiences and qualifications in Asia and elsewhere. In the University sector, Waters (2006b) writing in geography has shown that the uncertain economic climate combined with the democratisation of higher education in Hong Kong (where larger proportions of young people are now gaining a higher education) has led middle-class young people to seek to gain positional advantage by acquiring an overseas degree, either at the undergraduate level or, increasingly in the context of credential inflation, through postgraduate study (Waters, 2009). This helps these young people maintain their privileged class status because: "an overseas educational experience is believed to indicate (in its bearer) fluency in the English language as well as less obvious qualities, such as confidence, sociability, 
cosmopolitanism and possession of valuable social capital” (Waters, 2005: 363). Return migration is often part of their logic as the value of this cultural capital is realised through transnational social networks within Hong Kong, leading to a preferential position in the labour market, for example highly prized posts working for transnational corporations.

Waters' Bourdieusian emphasis on the importance of educational qualifications as an institutionalised form of cultural capital which reproduces middle-class advantage in contemporary Asia is mirrored by recent research elsewhere in the social sciences. Reproducing their class advantage was a key concern of Kim’s (2011) Korean graduatestudent interviewees who were studying in the USA; while in China, where social and economic inequality is growing rapidly, the emerging middle-class has responded to the expansion of higher education, and the consequent devaluing of local degrees, by funding international study opportunities for their children, and in the process legitimating their often recently acquired financial capital through its conversion into cultural capital (Xiang and Shen, 2009). ${ }^{2}$

In the school sector, education has been conceived in the geographical and wider literature as a key 'project' for middle-class Asian families (Huang and Yeoh, 2005). The importance attached to education is argued to be rooted in the importance of Confucian philosophy in the region: its emphasis on filial piety is seen to lead to a greater emphasis on the parent-child rather than the marital bond, with children's success being regarded as "the family fame or prosperity" (Lee, 2011: 396). This value placed on children's success, when coupled with the massification of higher education and highly competitive local education systems where failure to perform extremely well limits children's progress into the best universities and jobs, is leading increasing numbers of middle-class Asian families to educate their children abroad. Educating children overseas both removes their offspring from the (potential) risk of failure in the local education system, and helps them acquire additional cultural capital, not least through the development of their English language skills (Huang and Yeoh, 2005; Waters, 2006b). The process has often relied on transnational family strategies where so called 'astronaut' or 'seagull' fathers remain in Asia in order to exploit economic

\footnotetext{
${ }^{2}$ By contrast, British students who study overseas sometime emphasise distinction but other factors like adventure can also be important (Findlay et al., 2012; Waters et al., 2011).
} 
opportunities which will support their families, but 'study' or 'kirogi' mothers move overseas with their children to support their education. The experiences of these mothers and children is quite varied, as while some in the economic elite (including those moving from Hong Kong and Taiwan to Canada, and Korea to the USA) have found the experience liberating after initial settling in difficulties (Lee, 2010; Waters, 2002), others (including those moving from China to Singapore) have struggled in the face of economic difficulties and local discrimination (Huang and Yeoh, 2005, 2011).

This overview of the literature to-date shows how a geographically differentiated higher education system - which includes expansionary drives from within the global North that play through targeted marketing to concerns about middle-class social reproduction in Asia - results in transnational mobility amongst students, and in some cases, their families. Bourdieusian analyses of the importance of overseas educational credentials in the accrual of cultural capital, and its deployment through transnational social fields, show the importance of this mobility in (re)producing the class advantage of established and recently emerged elites (Lee, 2011; Waters, 2006b; Xiang and Shen, 2009). In so doing, the research makes undoubted contributions to geographers' renewed interest in social class, one that now includes an appreciation of the importance of transnational contexts (Dowling, 2009).

Our aim in this paper is to contribute to this strongly emerging literature in two ways. Firstly, we want to broaden the spatial frame of the field (Holloway et al., 2010). Research on East-West international student mobility has been important in challenging the Northern centricity seen in the wider field of geographies of education, but here we want to expand the existing attention to major student flows which originate in East Asia, by focusing on the emerging educational markets which are developing in the former Soviet republics in Central Asia. Education has become a key concern for leaders in the these post-transitional economies as an already effective system is now being asked to meet "the new demands of ethnic nationalism, a globally competitive economy, and a labour market freed from administrative control” (Anderson and Heyneman, 2005: 361). The economic upheaval which accompanied the transition from communism to capitalism has also placed education high on the priority list of many middle-class parents who did well under the former Soviet system, as it is seen as key in ensuring that their children can enjoy access to similar quality employment and lifestyles as the previous generation (Roberts et al., 2009). Rather than mask the differences between the five independent Central Asian states by considering them as a 
whole, we focus in this paper on students' experiences of educational mobility between one of these nations, Kazakhstan, and the United Kingdom. As we explain in more detail later, Kazakhstan is a particularly apposite choice as the President Nazarbayev has identified international study by young people as crucial to the on-going development of the country (OECD and The World Bank, 2007).

Secondly, we want to contribute a gendered analysis to a field that has largely been shaped by Bourdieusian understandings of social class reproduction. Our intention is not to throw out the baby with the proverbial bathwater, as our review above demonstrates the positive insights that have been produced through this form of analysis, and attention to the reproduction of social class therefore remains important in this study. Rather, what we want to do is combine this interest in class with an approach which challenges the relative silence around gender and family life in geographical writing in the field (cf. McDowell, 2008 on wider silences around gender in class analysis, and Valentine , 2007, on the importance of intersectionality in feminist geography). There is valuable research which explores the gendering of academics' mobility (Jöns, 2011) and transnational educational strategies from the perspectives of parents (e.g. Huang and Yeoh's (2005) work on the 'sacrificial' role of mothers who accompany their children to study in Singapore (see also Waters, 2002)). However, while the twenty-first century has seen rapidly increasing academic recognition of the gendered nature of migration (Bastia et al., 2011; Yeoh et al., 2000), there is a striking silence in geographical writing on the gendering of educational mobility from the perspective of undergraduate students, and it is this lacuna which this paper seeks to fill.

Findlay (2010) provides brief data on the proportions of international students who are male/female from different source regions, noting that while there is a bias in these figures towards men this is often less exaggerated than in these students' home education systems. What is required now is a classed and gendered analysis of how these students seek to acquire cultural capital through overseas education and crucially, in terms of gender, how they hope to convert this into positional advantage after graduation. There are hints in the wider social science literature that these might be important questions. Ono and Piper (2004: 103) argue that Japanese women undertake MBAs in the USA to avoid discrimination in their national labour market; however, theirs in not a paper based on empirical research and, while it points to the importance of our research agenda, it intentionally 'raises more questions than answers'. More recently, Lee (2011) highlights gender discrimination in Korea as a push factor for 
women to undertake graduate studies in the USA; while Xiang and Shen (2009) note that gender discrimination in the Chinese job market - and the desirable position in which having a foreign degree places women in the marriage market - can influence the decision to study abroad. In neither of these cases is gender (or indeed contingent forms of heterosexuality) the primary concern of these authors, and thus whilst they raise its prospective importance (for women at least) this remains to be more thoroughly analysed. In so doing, it will be crucial to explore the gendered experiences of men alongside those of women. To do this end, we now turn to our case study focus on undergraduate students from Kazakhstan studying in the UK and provide details of our methodology.

\section{Research context and methodology}

Kazakhstan is the most northerly of the five Central Asian Republics which gained independence from the Soviet Union in 1991. Its 'transition to independence has been' Koch (2010: 783) notes 'comparatively smooth, with President Nazarbayev retaining a firm, authoritarian hold on political power'. Although the immediate postindependence period saw an economic crisis (O’Hara and Gentile, 2009), currency devaluation in the wake of the 1998 Russian financial crisis proved a turning point for the country. Since then there has been huge economic growth, largely fuelled by developments in energy and mining, with Kazakhstan's economy out performing virtually all of the former Soviet states. The country was hit hard by the global economic crisis which began in 2007 (O’Hara et al., 2009) but by 2010 it had returned to strong economic growth (CIA, 2011a). The distribution of wealth is an issue for all countries, and poverty along with youth un/underemployment is an ongoing problem in Kazakhstan (Roberts, 2010).

The 15.5 million population of Kazakhstan is diverse: the two key national groups are Kazakhs (63\%) and Russians (24\%), with Uzbeks, Ukrainians, Uighurs, Tatars and Germans being the largest groups in the remaining $13 \%$ of the population. This diversity is reflected in religious differences, with Islam (which is strongly associated with Kazakh identity) being the largest religion, followed by Russian Orthodox Christianity (CIA, 2011a; Omelicheva, 2011). The government has used the term 'Kazakhstani' to blur the distinctions between these national groups, and likes to present Kazakhstan as both the place where East meets West, and as the crossroads of the major world religions. In reality, however, since independence there has been a 
“Kazakhification” of society with the "de facto privileging of ethnic, Kazakh-speaking Kazakhs over other groups” (Koch, 2010: 770).

Education has been conceived by the Kazakh government as playing a key role the country's economic and political development. It inherited an effective and inclusive system from its Soviet past, and today children continue to benefit from universal access to primary and secondary education (UNICEF, 2011). The local higher education system is also well developed, and rapidly increasing participation rates now mean $44 \%$ of $19-24$ year olds are in tertiary education, although none of the state and private universities make it into the rankings of the World's best universities (OECD and The World Bank, 2007). National education alone was not seen by the government as sufficient however, and following the example of other nations such as Japan, Turkey and Hong Kong who were viewed by the Kazakh leadership as having built economically and politically viable states by actively learning from 'the most advanced education systems in the world' (Embassy of the Republic of Kazakhstan, 2011, unpaginated), Kazakhstan was the first of the Central Asian states to launch a statesponsored programme to support study abroad. As President Nazarbayev (1993, cited in Embassy of the Republic of Kazakhstan, 2011, unpaginated) argued:

“In Kazakhstan’s transition towards a market economy and the expansion of international contacts, there is an acute need for cadres with advanced western education, and so, it is now necessary to send the most qualified youth to study in leading educational institutions in foreign countries”

The Presidential Bolashak Scholarship Programme fully funds high-achieving students to study undergraduate and postgraduate degrees abroad in order to train future leaders in business, international relations, law, science and engineering. An estimated 30 to $40 \%$ of these students travel to the UK, with the USA and Russia being the other major destinations. After graduation they are required to return to work in Kazakhstan for five years to contribute to the development of the nation, a return the scheme seeks to enforce by using students’ parents as collateral guarantors (with scholarships usually being secured against parents' homes). In addition, some very well-off parents pay for their off-spring to study overseas (OECD and The World Bank, 2007).

In this paper we explore the motivations of 20 students who have moved from Kazakhstan to the UK to undertake undergraduate degrees, and how they expect to use 
their education in the future ${ }^{3}$. The interviewees, who include 10 men and 10 women aged between 20 and 23 in their final year of study, were recruited through university admissions and international offices, student societies and via Facebook. Seventeen of these students were Bolashak scholars, reflecting the importance of the programme, but three were self-funded. None of the students we interviewed came from financially impoverished backgrounds. Some were very wealthy: this included those self-funding, but others on Bolashak Scholarships had parents who could have afforded to pay for an overseas education. Others described themselves as middle-class (they had professional parents and assets on which the Scholarship could be secured) but not as part of the rich elite who could afford to buy a Western education without Government help. The majority (14) of these students were of Kazakh ethnicity, three described themselves as having a mixed background, and a further three came from the minor nationalities in Kazakhstan. The students were also mainly from a Muslim background though they varied significantly in terms of their devotion to the faith: nine described themselves unproblematically as Muslim, and a further seven described their cultural background as Muslim but emphasised that they were not strict/practicing Muslims. Their attitudes reflect the position of Islam in Kazakhstan: according to Omelicheva (2011: 246) while 'being Kazakh means being Muslim’ (p.246), many are only light observers of Islamic laws, and in the 2000s the Kazakh leadership has started to present 'radical 'Islam as a threat to the country (see also Ro'i and Wainer, 2009). Of the remaining students, three had no religion, and one was Christian. The semi-structured interviews, which lasted on average two hours and were conducted in English, explored students' motivations for and experiences of studying in the UK, and the role they thought that studying overseas would play in their future life. The interviews were transcribed and interviewees allocated pseudonyms for use in the storage, analysis and publication of the data.

It is to an analysis of this data that the paper now turns. We begin by examining similarities, as well as differences, between Kazakh students' accrual of cultural capital and that of their East Asian counterparts. The subsequent section explores the importance of gender, as well as heterosexuality and religion, in this class project as

\footnotetext{
${ }^{3}$ The students studied at 12 pre- and post-1992 institutions, usually in subjects valued by the Bolashak Programme. To maintain interviewee anonymity we do not specify their degree or institution. None were our own students.
} 
students articulate the connections between educational qualifications, employment and family life.

\section{Cultural capital, gender, and international student mobility}

\section{Setting oneself apart}

The Presidential Bolashak Scholarship Programme funds overseas study for some of the country's brightest students in order that they can return and contribute to the development of Kazakhstan. The vast majority of students we interviewed either embraced or accepted this rationale and expected to return to live and work in Kazakhstan in a field related to their degree specialism. Echoing their President's words about the importance of international education (Kazakh Embassy, 2011), some of these young people suggested that returning from overseas study would enable them to contribute to the development of Kazakhstan, illustrating the role international education can play in the contested process of nation-building (Madge et al., 2009): Kazakh students who come here, they quite patriotic and they want to come back to their country and move forward, move forward the country... I hope the knowledge that we obtained here will be very useful for the country when I get back. (Ravil, Male)

[I] wanted to make some contribution to my country and learn something and to bring my experience to my country ...I would love to contribute. (Raumila, female)

I'll do my best to have some changes in Kazakhstan...we have plenty of problems in Kazakhstan, the main is corruption... if this will be changed many other things will...one of the main things I like now in Government is the scholarship because they manage to send a lot of students to study abroad and ... they will have different attitudes ... and I guess that will bring something new to our country, brings some challenges to our country. (Kemhebek, male)

Notwithstanding any patriotic aspirations, the students also had personal ambitions in wanting to study abroad and, based on their understanding that higher education alone was not enough, chief amongst these was a desire to make themselves stand out in a competitive domestic labour market where 'there is chronic congestion at the ports of entry into professional middle-class careers’ (Roberts, 2010: 546). 
Recent dramatic increases in higher education enrolment in Kazakhstan (Anderson and Heyneman, 2005; OECD and The World Bank, 2007) have reduced the value of local degrees (cf. Xiang and Shen, 2009) and enhanced individual graduates' need to set themselves apart in a country where there is an oversupply of qualified young people for service class employment (Roberts et al., 2009). This position has resulted in those families who were advantaged under the Soviet system using 'new tactics' - including paying for English language classes, private tutors, and private sector education - in order to facilitate the intergenerational transmission of class advantage (Roberts et al., 2009: 77). Securing positional advantage in the labour market and transforming one's future life chances was the overt aim of the young men and women we interviewed, suggesting that like their East Asian counterparts (Huang and Yeoh, 2005; Kim, 2011), overseas education is the latest strategy in Central Asia as young people of both genders seek to (re)produce middle-class identities in changing economic circumstances (Roberts, 2010):

[I]f you have international level diploma, it’s completely different level and different opportunities. (Alnura, female)

[I]f you get a diploma from abroad, especially UK diploma, so you will get a chance to get a high salary and you will get a chance to get a job (Askar, male) The number of students who have graduated abroad is much less than the number of students that graduated at home...so it should be an advantage. (Meirzjan, male)

Unlike in East Asia, however, the state-funded Bolashak scholarships means that the opportunity for overseas study is not only open to those who can self-fund, but to a wider range of academically-able young people. In practice, these are largely middleclass young men and women from families who may or may not be able to afford an overseas undergraduate degree, but who have given their children experiences, such as overseas travel and private English language tuition, which later allowed them to excel in the selection process (a process itself which has drawn allegations of corruption). As Baltabek, whose highly-educated parents could not afford to pay for him to study overseas but did pay for him to have private language lessons after school, puts it succinctly:

The three years I have spent studying English were very helpful for my Bolashak. (Baltabek, male) 
Moreover, coming from families with sufficient financial assets on which the Bolashak studentship could be secured (usually the parental home) further eased middle-class children's path into overseas study.

A key driver of international student mobility in this study, as elsewhere, was the desire to obtain a qualification that would make them stand out from other graduates in their chosen labour market (Waters, 2009; Xiang and Shen, 2009). For the vast majority of students this labour market was the domestic one, as there is a geographic logic to their cultural capital. The scholarships which give them access to overseas education have return to Kazakhstan as a precondition, and the use of parents as collateral guarantors (OECD and The World Bank, 2007) meant many felt obliged to do so. Moreover, while their overseas degree will make them standout in Kazakhstan, the same is not true in the UK where they would have to compete with local graduates:

I would like to stay here because I like this country, I like people here... But the problem is...it would be very difficult for me like to find a good job here...my passport is not European, English not my first language, so it would be a problem. So I've got to go back home and find a decent job there.

(Damira, female)

Unemployment's really high, it's getting really high because of the financial crisis ...even the British people are unemployed...maybe I won't get any chance to get like a job...it's quite difficult to stay. (Askar, male) By contrast, only a small minority of students, who were not bound by or thought they could afford to circumvent the Bolashak Scholarship condition that they return to Kazakhstan, pursued a different geographic logic, studying for a UK degree because the uneven structure of the global higher education market would make this more valuable in an international labour market than its equivalent from Kazakhstan:

[I]t provides opportunities to actually really work anywhere where I want because it's an internationally recognisable institution. (Zemfira, female)

Although much of the geographic logic of this cultural capital parallels that seen in other studies, there are important differences in the way it can be deployed on return to Kazakhstan. Waters (2006b) has highlighted the importance of transnational social networks in enabling Canadian-educated students to gain employment in MNCs on their return to Hong Kong. In the case of Kazakhstan, students are emphatic that it is local social networks, not transnational ones, which are crucial in a graduate’s ability to secure employment: 
If you want to be an official, work for Government...just work in national company....like oil industry or something, you better have good network, like or your parents have good network, so then they call someone and then you get a job! That’s how it works! (Talgat, male)

It's not that difficult to get a job in Kazakhstan, but it's more complex if you want to get high position. First of all you need to know the right people and be a relative of the boss ...I will definitely need my mum's help. Every single person would use their relationship, friendship to get a better position. (Alnura, female) Their views, in this respect, are in accord with Roberts et al. (2009) who found that approximately half of young people in Kazakhstan found out about their first jobs through family or friends, and a quarter thought that connections had been decisive in their appointment.

The ongoing importance of local social capital in Kazakhstan, however, does not wholly undermine the value of educational qualifications as a form of institutionalised cultural capital (Bourdieu, 1986). While social capital undoubtedly matters, having an overseas degree allows students to culturally transmit 'the right signal' to an audience 'far beyond the bounds of any individual's or family’s social network' (Roberts et al., 2009: 76), and in our study recruiters in MNCs and international organisations were key targets for this message. Some students, most often women but also men who lacked useful connections, were keen to work for these organisations because their recruitment policies are seen to be fair (Ono and Piper, 2004), valuing cultural capital over connections:

I would more appreciate if I would be hired for my abilities and for my brain and for my experience, not for who my uncle or father or whoever is. It is different in [MNCs] because they are not controlled by Kazakh people. (Zulfia, female)

[I]nternational companies are better because they consider it equally...[they're] not Kazakh heads, like they're from UK or America, or whatever and they don't know people. (Raumila, female)

I would prefer international company because I believe they would appreciate my skills more. (Baltabek, male)

Some students also argued that recruitment processes were shaped by ethnicity, suggesting that international companies and private businesses were more open to minority groups than recruiters in Government or national companies. However, the 
impacts of the Kazakhification of society were strongly contested by others (including some from minority groups) producing a mixed picture in our data.

Thus we can see that acquiring cultural capital through overseas education is one way in which these young people, like their East Asian counterparts, seek to (re)produce economically advantaged middle-class status. The spatial specificity of this process is seen, however, in the significant role played by the state in shaping access to overseas education for a wide variety of middle-class young people, a factor that produces patriotic as well as individualistic explanations of their desire to study overseas. Moreover, local social networks, and in particular family contacts, play a very important role in securing preferential access to the labour market. At first sight, young men and women describe the accrual of cultural capital through overseas education in similar ways, a fact which has underpinned gender-neutral analyses of international student mobility in a range of contexts (Findlay et al., 2012; Waters, 2009). However, the greater emphasis women place on searching for employment in which their educational qualifications will be recognised suggests that we need to move beyond purely classbased analyses of the geography of cultural capital. To this end, we now examine how young women, and then young men, envisage realising this cultural capital in the interconnected social fields of paid employment and family life.

\section{Gendering cultural capital: young women, employment and family life}

Cultural capital, for the young women in our study, was not a gender-neutral attribute but something they were aware they would need to seek to deploy in a patriarchal culture. Realising the value of their cultural capital in the labour market would be more difficult for them than men, as this particular social field is shaped by gender-based discrimination. Under Soviet rule, official policies about gender equality lead to high literacy and labour force participation rates amongst women; yet the labour market remained highly gender-segmented as women sought to balance labour obligations with domestic responsibilities that remained largely unchanged (Kandiyoti, 2007). This history of female education is reflected today in the fact that more young women than men enrol in higher education (Anderson and Heyneman, 2005), but gender-based segmentation and discrimination in the labour market are an ongoing concern for young women:

There is a gender bias, like if you work in Government bodies...it's like eastern or Muslim, like Kazakh mentality where like a woman's place is at home, some 
people genuinely believe in it, some men genuinely do. And ... again it's all about networks ... most like members are men. (Damira, female) Indeed, in the post-Soviet period there has been 'an official restoration of male privilege as an item of national culture' (Kandiyoti, 2007: 613). As the young women's male counterparts make clear:

Companies prefer men, probably they can spend much more time in work. Woman have, if she have a family, have to spend time with family, but men, more flexible in their working hierarchy. He is ... more stress resist[ant]...More organised probably.... men is leader in Kazakhstan. (Dilnaz, male)

The cultural capital that women acquire through overseas study in not something they can plan to take home to a level playing field. Rather, their strategies for securing a successful future necessarily take gender-based discrimination into account. Young women's enthusiasm for working for MNCs can be read as one response to such discrimination in the home labour market, as these companies' greater emphasis on qualifications is presumed to help women, especially those without connections. Other strategies include avoiding heavily male dominated sectors of employment, such as science and technology. Raumila, for example, is studying for a degree that would ordinarily lead to employment in this field, but her fear of discrimination is sufficient to cause her to plan to search for work in alternative sectors:

I don't want to get (specialism)-related job because... when someone wants to make a choice whether to take a man or woman, they definitely take a man. (Raumila, female)

Zemfira by contrast, who is a self-funded student, has avoided this by securing graduate employment in the UK where she feels her abilities are more highly valued.

Young women's ability to realise the value of their cultural capital is not only shaped within the labour market, but crucially also within the family, and more specifically, heterosexual marriage. Heterosexuality is spatially contingent (Walsh et al., 2008), and in pre-independence Kazakhstan pro-natalist/maternalist policies combined with Islamic culture to support 'the Soviet paradox', namely that female education and labour force participation coexisted with high fertility rates and an untransformed domestic division of labour (Kandiyoti, 2007: 607). Post-independence, localised forms of Islam (Ro'i and Wainer, 2009) continue to shape the life-course expectations, with women marrying in their early twenties and having above replacement level fertility 
(Roberts, 2010). In a context where men are seen as leaders, and where women have considerable domestic responsibilities and may be expected to defer to their husband's authority, women's employment can be cast as a hobby:

[B]ecause Kazakhstan’s a very conservative country... some men, when they get married, they prefer their wives to stay at home, they don't like them to work, and they kind of think that work is not for woman because the idea is like man brings the money home and he supports the family ...it's a bit unfair actually...they think that work for woman is like a hobby, instead of sitting at home they want to do something. (Aulim, female)

The distinct gender roles on which the locally contingent forms of (compulsory) heterosexuality rest make gender-neutral evaluations of cultural capital impossible. Mai and King (2009: 297) have argued that love and sexuality are under-researched dimensions in mobility studies, questioning how we can separate 'a migrants desire to improve the well-being of her/his family from ...existing gendered understandings of responsibility, morality and care'. For some young women in our study, the contingent nature of heterosexuality in Kazakhstan shapes their habitus in line with the reality that they expect to meet upon their return home, meaning they have little intension of maximising their cultural capital in the labour market:

[B] ecause I am woman, I have to have a family, run for it and maybe [do] some kind of work which doesn't need me to be there all the time ... [women] have to run all the family, they had to run children and so on, so it’s quite challenging to do it together, you've got to find the work which won’t be so, you know which won’t need so many efforts. (Galia, female)

Though marriage and childbearing may be earlier in Kazakhstan than for middle-class women in the urban-West, this pattern of fitting work around family responsibilities clearly has parallels with the one-and-a-half-earner family model in Britain, where many women work part-time around family responsibilities (Lewis and Campbell, 2007).

For others, however, the experience of studying overseas has reshaped their aspirations (cf. Bastia et al., 2011), making employment a more central part of their lives:

Since I studied in UK I saw another world from Kazakhstan...I think it increases what I want to achieve from my life and what I want my family be like...[If I 
hadn't studied abroad] I think if my husband wanted me to stay at home, I think I would have agreed, but now I think I wouldn’t! (Liazzat, female) [There is a] normal Asian mentality, the woman does every [household] job, everything. And I think it's just the psychology they think, if you keep saying 'oh women can't do that' then it will be true. I keep saying, I keep believing and I keep thinking that if I want to do that, if I want to be that [high powered professional] I will be. (Venera, female)

Nevertheless, all the young women in this study also placed great value on their role as mothers, and thought it went without question that they would want to have children. This left those very ambitious in relation to work with ambivalent feelings as childbearing was seen to have an inevitable impact on women's careers. They hoped that they would be able to combine high quality employment with childrearing, but were concerned that perhaps they were aspiring to something they might not be able to achieve:

There's a Russian famous play... the main idea is that sometimes too much education makes you too smart and too qualified for certain things. So sometimes it's better to be, I don't know, more grounded and not have high aspirations because ... you already think that you deserve something better so you just [keep] look[ing] for it. (Gulnara, female)

These women recognise that if they are to convert their cultural capital into class advantage what they need is not the transnational social networks that aided the graduates in Water's (2006) study, but a suitable husband. Xiang and Shen (2009) note that studying overseas can improve Chinese women's position in the marriage market, while Ono and Piper (2004) suggest the opposite might be the case for women from Japan. Our research suggests the process is complex in Kazakhstan. Firstly, these young women feel they have to find a well paid husband if they are to fulfil their own work potential, as in this social field it would be unacceptable for them as a wife to earn more than their husband:

[W]ell husband has to earn more money than wife, because if wife earns more it like, it affects his self respect maybe, self esteem...In this sense I think it would be difficult for girls who study abroad, because it really levels up the rank of husband who we are looking for. (Liazzat, female)

I want to see [my current boyfriend] start working and yeah I guess think about what kind of husband he will be and then start thinking about marriage and 
stuff....if I get a good job, [in my specialism] they get well paid, and so there might be a possibility that I might be earning more and that's not acceptable for the guy, so there might be a problem [about marrying him]. (Aulim, female) Secondly, they also have to find a husband with egalitarian ideas about gender relations, as they will be unable to exert their independence in a marriage with a man who thinks women's role should be confined to the home:

I'm hoping to get career and apply all the skills that I have learnt. I just don't want it [my education] to go to waste I think... if I go back, get married and have 5 children and don't work, this is how it's going to go to waste!...I'll try to find a job and a man who doesn't, he's not really narrow minded and doesn't say the only place for me is kitchen. (Gulnara, female).

Studying overseas is an important process in middle-class social reproduction for these academically-able young women. However, as this analysis has shown this class process is not about class alone, but is intimately shaped by young women's gendered expectations as aspiring middle class citizens, both in the context of a discriminatory labour market and in the realm of localised forms of heterosexual marriage.

\section{Gendering cultural capital: young men, employment and family life}

The cultural capital men acquire through international study is experienced in very different ways than that acquired by the women. The men themselves are strikingly diverse. Some are conversant with debates about gender equality and regard women as equals in education and the workplace, though few would radically disrupt the gendered division of labour within the home. Others see men as leaders, women as nurturers and expect women to defer to male authority:

I’m not sexist! So I always consider myself, like woman and men are the same, so if they have a similar rights, they have to have similar responsibilities.

(Kemhebek, male)

We are Muslims, it’s make a difference in relationship between men and women...I think 'til [children are] 10..a wife have to stay at home to look for the childrens....Looking for the childrens, cooking, looking for house...[My future wife will be] younger than me, I think she won't raise her voice against me. That's why it's important to have a younger wife. She shouldn't be on the same 
level...I mean she have her freedom as a person, but every decision she should ask, check with me. (Dilnaz, male)

This diversity in views reflects the impact of both Soviet discourses on equality (Kandiyoti, 2007) and localised versions of Islam (Omelicheva, 2011) on gender relations in Kazakhstan. Regardless of their individual views, however, these young men will be returning with an international degree to a country where it is more advantageous to be a man in the labour market than a woman:

Kazakhstan actually is more male dominated country than UK and Europe.

Now there are many talks about how to empower women...But still in top management and top politics positions, male of course still dominating about $90 \%$ of things. (Meirzjan, male)

They are therefore better placed than young women to realise the value of their cultural capital in this social field, and their position seems more akin than women's to the graduates seen elsewhere in research on educational mobility (Waters, 2006 a and b).

The labour market, however, is not the only social field in which this cultural capital matters. For young men - just as for young women - educational opportunities, lucrative employment and successful family life are intimately connected. Young men, particularly those of Kazakh ethnicity, hold an advantageous position in the labour market, but the pressures upon them to succeed are also greater if they are to live up to their image of what it means to be a good man. Cultural capital institutionalised through the accrual of an overseas education (Bourdieu, 1986) is therefore particularly valuable to young men in this cultural context who need to secure decent employment in order to earn enough to keep not only themselves but also their wives and families:

I’m probably planning to get married when I will be 26, 26 probably, maybe earlier if I will get, if I will be able to earn enough money to get my family living ....I have to be educated if I want to be good husband, if I want to keep my family OK all the time. (Kemhebek, male)

Man is... head of the family and he has to bring the food...like being the supplier for the family. (Ravil, male)

Moreover, not only do young men need a decent income to cover family expenses, it is very important that they earn more than their wives:

He [husband] has to earn money more than a woman...because the woman are considered as a weak gender and we are strong gender, so we have to provide. (Azamat, male) 
We have a very clear division in the family that...woman have to like grow, care about the children and men...should go and get money...I would not expect my wife to earn more than me...From what I saw most couples, when the woman earns more than a man, they broke up. (Tamerlan, male)

The pressure for men to accrue sufficient cultural capital to succeed in the labour market is even stronger now than in Soviet times. This is partly a result of cutbacks in state support, most obviously housing (which made marriage without financial assets easier), but is also related to the move to a market economy where work is seen as the way to get ahead in life and is intricately bound up with social status (Kandiyoti, 2007; Roberts, 2010). The educational capital that these young men have acquired in the UK is thus vital to their future success in appealing to a potential wife. Though understandings of commitment may override the importance of money in women's intention to marry elsewhere (Wiik, 2010), here young men expect women to use finance as one measure of their suitability as a husband:

Now marriage choices are more controlled by your status in the society... men won't be concerned about the status of a potential wife but woman are much more concerned, because for woman if she marry, if she will sit at home, and men will bring her money. (Dilnaz, male)

[She] has to like think about the financial condition of the husband she's going to marry ... somewhere there, like an instinct, she’s already taking care of her unborn children. (Ramazan, male)

The responses of young women make clear that the notion that men should earn more than women, and that finances are important in judging the suitability of a relationship, is shared by both genders:

Female friends in Kazakhstan, whenever we used to say that if you fancy someone, the first question they ask: 'what kind of car he has?'; 'what kind of flat he has?'; 'where does he live?’; ‘does he work?'; 'are his parents like wealthy?'. That's the first thing they ask. (Alnura, female) We discussed above how those young women who were keen to progress as far as possible in their careers needed a highly paid husband to make this a possibility. However, those who envisaged working part-time or in occupations they found less demanding, as was common in the Soviet period (Kandiyoti, 2007), also articulated the importance of a high earning husband. As Galia puts it, men's role is: 
To work and to find money...not just small amount of money but normal amount of money to provide normal living for children and for parents and for ourselves. (Galia, female)

In Raumila's case she was clear that her current partner's low income was an impediment to marriage:

I really afraid to get married because now my boyfriend, he doesn't earn that much......he afraid that I will get, earn much than him....it hurts male pride...I feel bad as well because I think men should be better than, like better than his wife, like he should be as idol for woman, like he has to lead a woman.

(Raumila, female)

Young men's privilege position in the labour market means that they are more likely than women to be able to take advantage of the cultural capital gained through overseas study and (re)produce themselves as economically-advantaged middle-class young people. This cannot, however, be read entirely as a class project in which men simply benefit from gender discrimination (although they do). More than this, the cultural capital which young men hope will enable them to be successful in the labour market is intricately bound up with their gender identities in another social field, specifically, their desire to succeed as men in both attracting and supporting a wife and subsequent children in the context of heterosexual family life which is often shaped by localised versions of Islam (Ro’i and Wainer, 2009).

\section{Conclusion}

This paper makes a twofold contribution to geographical debates about international student mobility and the role educational qualifications, as an institutionalised form of cultural capital, play in middle-class social reproduction. Firstly, we have broadened the spatial frame away from East Asia to focus on the emerging educational markets in the post-Soviet states of Central Asia through a case-study on Kazakhstan. This shift in geographical focus has been useful in highlighting parallels but also a significant degree of spatial specificity in the role of overseas education in reproducing the middle-classes. For these students, the key driver of their mobility was a desire to obtain a qualification that would make them stand out from other graduates in their chosen labour market, and thus (re)produce themselves as economically successful citizens (Waters, 2009). However, while the class advantage sought through the acquisition of cultural capital 
was the same as for student from elsewhere in Asia, other elements of the process were place specific.

Significantly, while a minority of students were self-funding, having rich parents who had made financial gains in Kazakhstan's shift from communism to capitalism in a process similar to that noted by Xiang and Shen (2009) in China, the student body in this study also included middle-class students whose families were comfortably off but could only afford to study abroad with state help. This highlights the role the state plays in Kazakhstan in broadening access to overseas education to a wider range of academically-able young people than is the case in many East Asian nations. This is not to say that family background is unimportant: parenting practices which rely on middle-class incomes and dispositions - for example foreign travel and private language tuition - continue to enhance these children's ability to win a scholarship over their poorer counterparts (Roberts et al., 2009). Nevertheless, the state's role in ensuring a wider range of middle-class children can study abroad explains why student mobility was not only rationalised through the individualistic narratives seen in other studies, but also in patriotic terms which emphasised students' desire to drive their nation forward (Kazakh Embassy, 2011; OECD and The World Bank, 2007). International education can, as both President Nazarbayev and these students attest, be bound up with homenation-building (Madge et al., 2009). Once accrued, the context in which these students seek to deploy their cultural capital is also different; while transnational social networks have been show to be important elsewhere (Waters, 2006b), in this case local social networks were of more importance in a country where family connections play a significant role in the labour market. Although some students wanted to challenge corruption in order to drive forward the development of their nation, there was widespread acceptance that currently 'who' is at least as important as 'what' you know in securing lucrative employment in the domestic labour market.

Secondly, we have built upon the existing analysis of crises in middle-class social reproduction as drivers of international student mobility by showing that gender and attitudes to family life matter in the deployment of education-based cultural capital. Although the importance of parents' gender has been studied elsewhere (Huang and Yeoh, 2005), students’ gender and the importance of sexuality (Mai and King, 2009) has been under researched. Our point is not that class does not matter; our own analysis shows that young people are seeking to use an overseas education to secure positional advantage and (re)produce themselves as economically-advantaged middle-class 
citizens. Rather our contention is that to fully understand this class process we need to trace the ways in which gender and attitudes to family life, and thus inevitably sexuality and religion, matter to the realisation of this cultural capital. It is by tracing the importance, limitations and consequences of this cultural capital through the interconnected social fields of paid employment and family life that we gain a fuller understanding of its role in the gender-differentiated processes of middle-class social reproduction.

To expand, the young women in this study will not return to Kazakhstan as gender-neutral graduates, in their job search strategies they will face discrimination in the labour market, and at home they will have to negotiate employment success in the context of specific forms of heterosexuality, often shaped by local forms of Islam, which mean they must marry well to ensure they have a husband who has a higher earning capacity than themselves and a positive attitude to women's employment. The young men, especially those of Kazakh ethnicity, will return to a more advantageous position in the labour market, but are under great pressure to secure highly paid employment as this both shapes their desirability to women as a marriage partner and their ability to fulfil men's designated role as the provider in heterosexual marriage and family life in this largely Muslim nation. Middle-class social reproduction then is the core driver of international student mobility, but it is experienced and played out in significantly different ways for men and women in the context of locally-contingent forms of compulsory heterosexuality (Walsh et al., 2008), patterns which themselves are often influenced by religion.

In conclusion, this study demonstrates the importance of having a broad spatial frame in research on international student mobility. This not only allows us to examine similarities in student strategies between different nations, but also differences in the nature, meaning and implications of flows between different parts of the world. As such, this study marks a step forward in that direction by adding the case of post-Soviet Central Asia to existing research on East Asia. More, however, remains to be done, not only in excavating the differences between the Central Asian states, but also more broadly in ensuring we have better spatial coverage in research on student mobility to the Global North, and consider for example flows involving Africa, the Middle-East and elsewhere. 
Moreover, the study also demonstrates the importance of a class analysis in studies of student mobility, but crucially of a class analysis which pays due heed to the importance of gender and sexuality, as well as ethnicity, religion and so on (Valentine, 2007). Changing social and economic circumstances mean overseas study is playing an increasingly significant part in middle-class social reproduction, but as we have shown here the realisation of this cultural capital is also shaped by students' gender and the locally-specific nature of heterosexual family life in a largely Muslim nation. Class matters, but we cannot ignore the fact that educational opportunities, lucrative employment and successful family life are tied together in very different ways for young men and women in this particular heterosexual matrix. It is by studying how class is made through its intersections with other axes of social difference that we will gain a fuller understanding of its importance in student mobility, as in mobility studies more generally.

\section{Acknowledgements}

The research was jointly funded by Sarah Holloway’s Philip Leverhulme Prize, her British Academy Mid-Career Fellowship and the University of Nottingham; we gratefully acknowledge their support. Thanks to Jo Waters for helpful comments on an oral version of this paper.

\section{References}

Anderson KH and Heyneman SP, 2005, "Education and social policy in Central Asia: the next stage of the transition” Social Policy \& Administration 39 361-80

Bastia T, Piper N and Prieto Carrón M, 2011, “Geographies of migration, geographies of justice? Feminism, intersectionality, and rights” Environment and Planning A 43 $1492-9$

Bourdieu P, 1986, “The Forms of Capital” in Handbook for Theory and Research for the Sociology of Education Ed JG Richardson (Greenwood Press, Oxford) pp.241-258 Brooks R and Waters J, 2009, “A second chance at 'success’: UK students and global circuits of higher education” Sociology 43 1085-1102 
Central Intelligence Agency, 2011a, The World Factbook

https://www.cia.gov/library/publications/the-world-factbook/geos/kz.html

Accessed:19.11.2011

Dowling R, 2009, “Geographies of identity: landscapes of class” Progress in Human Geography 33 833-9

Embassy of the Republic of Kazakhstan, 2011, "Bolashak Program”

http://www.kazembassy.org.uk/bolashak_program.html Accessed:19.10.2011

Findlay AM, 2010, “An assessment of supply and demand-side theorizations of international student mobility” International Migration 49 162-190

Findlay AK, King R, Smith FM, Geddes A and Skeldon R, 2012, "World class? An investigation of globalisation, difference and international student mobility" Transactions of the Institute of British Geographers 37 118-131

Higher Education Statistics Agency, 2011, “Student Introduction 2009/10” http://www.hesa.ac.uk/index.php/content/view/1974/278/ Accessed:18/10/2011

Holloway SL, Hubbard P, Jöns H and Pimlott-Wilson H, 2010, “Geographies of education and the significance of children, youth and families” Progress in Human Geography 34 583-600

Huang S and Yeoh BSA, 2005, “Transnational families and their children’s education: China’s ‘study mothers’ in Singapore” Global Networks 5 379-400

Huang S and Yeoh BSA, 2011, "Navigating the terrains of transnational education: children of Chinese ‘study mothers’ in Singapore” Geoforum 42 394-403

Jöns H , 2011, “Transnational academic mobility and gender” Globalisation, Societies, and Education 9 183-209

Kandiyoti D, 2007, “The politics of gender and the Soviet paradox: neither colonized, nor modern?” Central Asian Survey 26 601-23

King R, Findlay A, Ahrens J and Dunne M, 2011, “Reproducing advantage: the perspectives of English school leavers on studying abroad” Globalisation, Societies and Education 9 161-181 
Kim J, 2011, “Aspirations for global cultural capital in the stratified realm of global higher education: why do Korean students go to US graduate schools” British Journal of Sociology of Education 32 109-26

Koch N, 2010, “The monumental and the miniature: imagining 'modernity' in Astana” Social \& Cultural Geography 11 769-87

Lee H, 2010, “'I am a kirogi mother': education exodus and life transformation among Korean transnational women” Journal of Language, Identity, and Education 9 250-64

Lee J, 2011, “Education and family in conflict” Journal of Studies in International Education 15 395-401

Lewis J and Campbell M, 2007, “UK Work/Family Balance Policies and Gender Equality, 1997-2005” Social Politics 14 4-30

Mai N and King R, 2009, "Love, sexuality and migration: mapping the issue(s)” Mobilities 4 295-307

Madge C Raghuram P and Noxolo P, 2009, “Engaged pedagogy and responsibility: a postcolonial analysis of international students” Geoforum 40 34-45

McDowell L, 2008, “Thinking through class and gender in the context of working class studies” Antipode $\mathbf{4 0}$ 20-4

O'Hara SL, Ivlevs T and Gentile M, 2009, “The Impact of the Global Economic Crisis on Remittances in the Commonwealth of Independent States” Eurasian Geography and Economics 50 447-463

O'Hara SL and Gentile M, 2009, "Household Incomes in Central Asia: The Case of Post-Soviet Kazakhstan” Eurasian Geography and Economics 50 327-347

Olds K, 2007, “Global assemblage: Singapore, foreign universities, and the constructions of a 'Global education hub'” World Development 35 959-75

Omelicheva MY, 2011, "Islam in Kazakhstan: a survey of contemporary trends and sources of securitization” Central Asian Survey 30 243-56

Ono H and Piper N, 2004, “Japanese women studying abroad, the case of the United States Women's Studies International Forum 27 101-18 
Organisations for Economic Co-Operation and Development and The World Bank, 2007, Higher Education in Kazakhstan

http://www.usp.ac.fj/worldbank2009/frame/Documents/Publications_regional/Kazakhst an\%20Higher\%20Education.pdf Accessed:19.10.11

Roberts K, 2010, “Post-Communist youth: is there a Central Asian pattern?” Central Asian Survey 29 537-49

Roberts K, Kamruzzaman P and Tholen J, 2009, “Young people’s education to work transitions and inter-generational social mobility in post-soviet central Asia” Young: Nordic Journal of Youth Research 17 59-80

Ro’i Y and Wainer A, 2009, “Muslim identity and Islamic practice in post-Soviet Central Asia” Central Asian Survey 28 303-22

UNICEF, 2011, “Kazakhstan: statistics”

http://www.unicef.org/infobycountry/kazakhstan_statistics.html Accessed:19.10.2011

Valentine G, 2007 “Theorizing and researching intersectionality: a challenge for feminist geography” The Professional Geographer 59 10-21

Walsh K, Shen H-h and Willis K, 2008, "Heterosexuality and migration in Asia” Gender, Place and Culture 15 575-9

Waters JL, 2002, Flexible families? ““Astronaut' household and the experiences of lone mothers in Vancouver, British Columbia” Social \& Cultural Geography 3 117-34

Waters JL, 2005, “Transnational family strategies and education in the contemporary Chinese diaspora” Global Networks 5 359-77

Waters JL, 2006a, “Emergent geographies of international education and social exclusion” Antipode 38 1046-1068

Waters JL, 2006b, “Geographies of cultural capital: education, international migration and family strategies between Hong Kong and Canada” Transactions of the Institute of British Geographers 31 179-192

Waters JL, 2009, “In pursuit of scarcity: transnational students, 'employability', and the MBA” Environment and Planning A 41 1865-83 
Waters J, Brooks R and Pimlott-Wilson H (2011) "Youthful escapes? British students, overseas education and the pursuit of happiness” Social and Cultural Geography 12 454-468

Wiik KA, Bernhardt E and Noack T, 2010, “Love or money? Marriage intentions among young cohabitors in Norway and Sweden” Acta Sociologica 53 269-87

Yeoh B, Huang S and Willis K, 2000, “Global cities, transnational flows and gender dimensions: the view from Singapore” Tijdschrift voor Economische en Sociale Geografie 91 147-158.

Xiang B and Shen W, 2009, "International student migration and social stratification in China” International Journal of Educational Development 29 513-22 